\title{
NORTHERN CARDINAL NESTING IN WYOMING
}

ROBERT D. DORN and JANE L. DORN, 8481 Road 39, Lingle, Wyoming 82223; linglebird@yahoo.com

CALVIN E. DYER, 2779 Power Plant Road, Lingle, Wyoming 82223

The Northern Cardinal (Cardinalis cardinalis) was first reported in Wyoming on the basis of John Clearwaters' observation of a pair along Bear and Horse creeks near LaGrange, Goshen County, date not specified (Grave and Walker 1913). McCreary (1939) reported that cardinals were being brought into the state in cages by the Mexicans and some may have escaped or been released. The cardinal has been reported from Wyoming at least 19 times since 1957 about equally in all seasons except winter, for which there are only two reports (Scott 1957, 1962, Downing 1990, Faulkner 2010, https://wybirdrecordscommittee.wordpress.com). The observations cover most parts of the state. But there have been no reports of nesting. The species has been classified as a "rare, irregular, yearlong visitor" (Dorn and Dorn 1999) or a "rare visitor" (Scott 1993, Faulkner 2010, https://wybirdrecordscommittee. wordpress.com).

In 2019 we observed at least two pairs of cardinals throughout the summer in brush-covered hills along the North Platte River about $3 \mathrm{~km}$ southwest of Lingle, Goshen County, Wyoming, but there was no evidence of nesting and the birds did not overwinter in the area. In 2020 at least one pair of cardinals returned to the same area. On 20 June 2020, Dyer observed an adult male with a fledgling. On the following day he observed the adult male feeding the fledgling (Figure 1). Later that day R. D. and J. L. Dorn observed the male feeding presumably the same fledgling

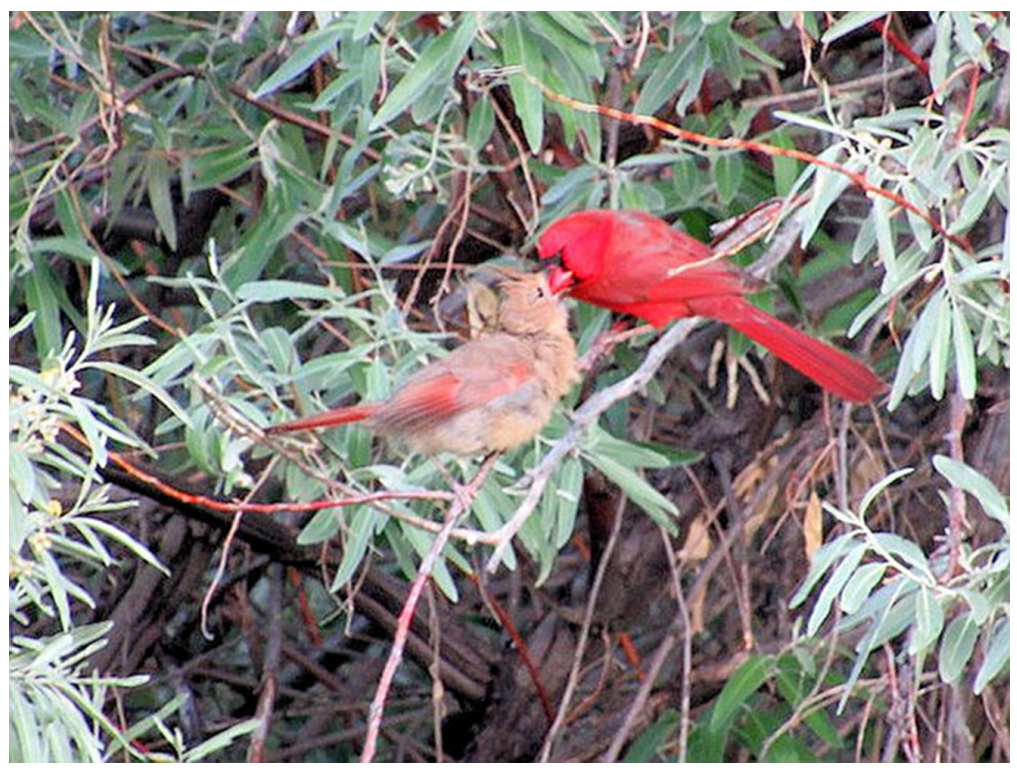

FIGURE 1. Adult male Cardinal feeding fledgling, Goshen County, Wyoming, 21 June 2020.

Photo by Calvin Dyer 


\section{NOTES}

at the same location (see this issue's outside back cover). No other fledglings were subsequently observed, although the female could have been feeding others elsewhere. This appears to be the first documented record of the Northern Cardinal nesting in Wyoming. In the winter of 2020-21 Dyer observed cardinals regularly at this same location. On 2 July 2021 he noted an adult male feeding three fledglings at the same location as in 2020.

The closest previously documented breeding of the species is about $60 \mathrm{~km}$ southeast of this location at Scottsbluff, Nebraska, where first confirmed in 1994 (Faulkner 2010). The species nests regularly from there and east across Nebraska. In Nebraska it is listed as more common in the east but has spread west in riparian woodlands and is now almost statewide (Farrar 2004). The observed breeding in Wyoming undoubtedly represents a continuing westward extension of the range along the North Platte River.

\section{LITERATURE CITED}

Dorn, R. D., and Dorn, J. L. 1999. Wyoming Birds, 2nd ed. Mountain West Publ., Cheyenne, WY.

Downing, H. (ed.). 1990. Birds of North-central Wyoming and the Bighorn National Forest. H. Downing, Sheridan, WY.

Farrar, J. 2004. Birding Nebraska. Nebraskaland Magazine 82:1-178.

Faulkner, D. W. 2010. Birds of Wyoming. Roberts and Co., Greenwood Village, CO.

Grave, B. H., and Walker, E. P. 1913. The Birds of Wyoming with an Explanation of Recent Changes in their Distribution, Economic Aspects Also Considered. Univ. Wyo., Laramie; https://doi.org/10.5962/bhl.title.3805.

McCreary, O. 1939. Wyoming Bird Life, rev. ed. Burgess Publ. Co., Minneapolis, MN.

Scott, O. K. 1957. Great Basin, Central Rocky Mountain region. Audubon Field Notes 11:367-368.

Scott, O. K. 1962. Great Basin, Central Rocky Mountain region. Audubon Field Notes 16:435-436.

Scott, O. K. 1993. A Birder's Guide to Wyoming. Am. Birding Assoc., Colorado Springs, CO.

Accepted 7 October 2021

Associate editor: Ryan S. Terrill 